\title{
Relationship between Tomato Yellow Leaf Curl Viruses and the Whitefly Vector
}

\author{
C. Ssekyewa ${ }^{1,} *$, P. V. Damme ${ }^{2}$, F. Nagawa ${ }^{3}$, S. Kyamanywa ${ }^{4} \&$ K. A. Steele ${ }^{5}$
}

(C) Uganda Martyrs University

\begin{abstract}
Tomato yellow leaf curl is prevalent in tomato growing districts of Uganda. The disease is known to be spread by a whitefly (Bemisia tabaci) in a persistent manner. Some of its symptoms are leaf curl, marginal leaf yellowing, malformation of fruits, stunting and dieback (in case of primary infection at early seedling stage), so the disease is economically important. Therefore, this study delved into the relationship between the disease and the vector in selected agro-ecosystems in the Country. The influence of weather and seasonality on the incidence of the disease and the vector was also investigated through a series of field experiments across a period of two years. New methods for trapping the vector were developed and applied to estimate its populations on individual plants and in the overall field environment. The findings were that whereas incidence of the disease is low at seedling stage, the whitefly population is highest at this stage. It was also found that the vector population is favoured by drought, so rainy conditions reduced it tremendously.
\end{abstract}

Keywords $\cdot$ Agro-ecosystem $\cdot$ Traps $\cdot$ Population dynamics $\cdot$ Management

La Relation entre les Virus de la Maladie de Feuilles Jaunes Courbées chez la Tomate et le Vecteur Mouche-blanche · Résumé $\cdot$ La maladie de feuilles jaunes courbées chez la tomate est dominante dans les districts cultivateurs de la tomate en Ouganda. Cette fameuse maladie est véhiculée par la mouche-blanche (Bemisia tabaci) d'une manière persistante. Certains symptômes consistent de feuilles courbées, limbes jaunâtres, malformation de fruits, atrophiassions (en cas d'une infection primaire au stade de germination), raison pour laquelle cette maladie est économiquement importante. C'est pourquoi, cette étude a examiné la relation entre la maladie et le vecteur dans quelques agro-écosystèmes dans le pays. L'influence de la température et de la saison sur l'incidence de la maladie et du vecteur a aussi été examinée par une série d'expérimentation sur terrain pour une période de deux ans. De nouvelles méthodes pour attraper le vecteur étaient développées and appliquées afin d'estimer leur populations sur les plantes individuelles mais aussi sur le champ écologique tout entier. Les résultats ont montré qu'alors que l'incidence de cette maladie est faible au stade de la germination, la population de mouches-blanche est élevée a ce stade. Il a été aperçu que la population du vecteur est favorisée par la sécheresse, et c'est pour cette raison que les conditions de pluie l'ont toujours énormément réduite. Mots Clé $\cdot$ Agro-écosystème, pièges, dynamique de population, gestion

\footnotetext{
${ }^{1}$ Uganda Martyrs University, *Corresponding author: cssekyewa@umu.ac.ug

2 Ghent University

${ }^{3}$ Fair Trade, Uganda

${ }^{4}$ Makerere University

${ }^{5}$ Bangor University
} 


\section{Introduction}

Tomato yellow leaf curl viruses (TYLCV) are transmitted by a vector Bemisia tabaci (Hemiptera: family Aleyrodidae) as reported by Cohen and Harpaz (1964). However, according to Czosnek and Laterrot (1997), there are sometimes variations in the mode of begomoviruses transmission by the same whitefly vector. These variations were reported in Egypt (Moustafa, 1991), where variations in tomato yellow leaf curl disease incidence were observed during spring (February-April), summer (September-mid-October) and autumn. Nono-Womdim et al. (1996) also reported variations in whitefly population and incidence of TYLCV in Tanzania.

In general, whitefly-borne viruses of the family Geminiviridae, to which begomoviruses belong, were recognized as major causal organisms of tomato diseases in the early 1990s (Padidam et al., 1995). In East Africa, whitefly-transmitted tomato leaf curl diseases were only recently reported (Nono-Womdim et al., 1996; Chiang et al., 1996) for the first time. However, until this study, nothing was known about TYLCV and its epidemiology and their relationship with whitefly vectors in Uganda. Previous studies, which were conducted in Uganda, focused on whitefly as a vector of cassava mosaic virus disease (Legg, 1996).

According to Polston and Anderson (1997), genetic changes occur in whitefly-transmitted geminiviruses. Based on this finding, and on the fact that TYLCV in Uganda are related to other already known begomoviruses (Ssekyewa et al.2009), we considered both viruses to be transmitted by the whitefly vector. This Polston and Anderson (1997) finding further implies that there was a need to have full knowledge of pathosystems through a multi-component approach. Therefore, this paper deals with field studies conducted with the objectives to determine: the general trend of whitefly population dynamics in relation to TYLCV disease incidence at different tomato growing stages and seasons in Buwama sub-county, Mpigi district; the effect of management practices on whitefly populations in this area; as well as the impact of management practices on TYLCV incidence and spread. In our hypotheses it was assumed, that whitefly populations vary according to changes in weather conditions, which also influence tomato planting date, growth and development, while incidence of tomato yellow leaf curl disease depends on whitefly population changes and farmers activities, like date of planting, weeding, as well as pesticide applications, which affect whitefly populations and in turn tomato yellow leaf curl virus diseases incidence.

\section{Materials and Methods}

An area in Buwama sub-county, Mpigi District where tomato yellow leaf curl viruses occurred, was selected for field experiments. The area had cassava (Mannihot esculenta), sweet potato (Ipomea batatas), maize (Zea mays) and banana (Musa spp.) as major crops, as well as Physalis floridana and Imperata cylindrica as major weeds. It also experienced a characteristic bi-modal rainfall regime.

The experiment was repeated three times between 1999 and 2000 to take care of annual dry and wet seasonal variations (Moustafa, 1991). As such, this period included two dry seasons and two rainy seasons, i.e. March to June (rainy season) and July to August 1999 (dry season), September to December 1999 (rainy season) and January to February 2000 (dry season). Each planting was done at the beginning or end of the wet season and ended in the dry season.

In all cases, variety Heinz was grown. Seedlings were raised on farm and sprayed once a fortnight with Dimethoate (30 ml in 151 of water) against whiteflies. In the field, a spacing of $90 \mathrm{x}$ $45 \mathrm{~cm}$ (Rice et al., 1987; Mwaule, 1995) was used. This resulted into a plant density of 50 plants per $30 \mathrm{~m}^{2}$, including guard rows. A randomized complete block design was used, and six treatments referred to as n1-n6 were applied, i.e.:

a) a tomato monocrop without spraying dimethoate, as a control treatment (n1);

b) a tomato monocrop with uprooting of TYLCV symptom-bearing plants (n2);

c) a tomato-bean intercrop without spraying dimethoate (n3);

d) a tomato monocrop with dimethoate sprayed once a week (n4);

e) a tomato monocrop with uprooting and dimethoate sprayed once a week (n5); 
f) a tomato-bean intercrop with bean rows sprayed once a week with dimethoate (n6).

Treatments were planted in three blocks, and therefore replicated three times in plots of $6 \mathrm{~m} \mathrm{x} 5 \mathrm{~m}$ each. Guard rows, which are normally planted with another crop that is not an alternative host e.g., maize, were established around experimental plots to minimize inter-treatment effects and also provide food to farmers. A blanket application of Mancozeb fungicide (50 g/15 1 of water) was fortnightly done for all experimental treatments. The experiment was weeded regularly with a hand hoe.

To keep track of whitefly population changes in the field as an alternative to turning over tomato leaves to count whiteflies present, or to using sunmica plates, vacuum collector and passive fan traps (Butler and Henneberry, 1989), cheap sticky Vaseline traps were used to trap and monitor whiteflies. Blue and yellow sticky traps (Figure1), with surfaces smeared with Vaseline, were fixed in the middle and at each corner of each treatment plot to guarantee maximum trapping of whiteflies in the general tomato ecosystem. These traps were made out of used 51 plastic jerry cans. They were modified from sticky traps reported earlier by Lewis (1973), Raccah (1986) and Green (1991). Thus, containers were cut into two pieces. Of the two pieces, the top part had a surface area of $0.015 \mathrm{~m}^{2}$, whereas the bottom part had a surface area of $0.075 \mathrm{~m}^{2}$ (Figure1).

Blue and yellow sticky plastic traps were repeated in all treatment plots. Note was made of number of whiteflies trapped per $\mathrm{m}^{2}$ every week. Counted whiteflies were removed from traps, which were then re-surfaced with fresh Vaseline to maintain stickiness. Traps made out of 51 plastic jerry cans trap flying whiteflies only, and were therefore used to monitor the general field whitefly population.

To monitor whitefly population on individual plants per plot, another type of trap that could be used to estimate number of whiteflies infesting a tomato plant was necessary. Consequently, the Kubwa sticky trap was made out of a plastic basin and a translucent bucket with a bottom diameter of $100 \mathrm{~cm}$, lower height of $45 \mathrm{~cm}$, upper diameter of $25 \mathrm{~cm}$, plus an upper height of $30 \mathrm{~cm}$, and with a translucent top inner wall surface smeared with Vaseline (Figure 2).

The Kubwa trap was purposely made to trap whiteflies as an estimate of the whitefly population density on individual tomato plants. This was to take care of the fact that whiteflies rarely lay eggs on tomato leaves. Therefore, counting of nymphs could not be performed as recommended by Butler and Henneberry, (1989). Counting adult whiteflies after turning over infested leaves is also not feasible, because many fly off before they are counted. To get an estimate of whitefly population density per plant per plot, the Kubwa trap was inverted on one plant at a time for at least 3 minutes. Ten plants were sampled per plot. The plant stem was shaken below to induce whiteflies to fly. Whiteflies escaping to the translucent part of Kubwa trap would be trapped on the sticky surface of the trap bucket. Trapped whiteflies were counted and removed from the trap. Data were taken on a weekly basis starting from transplanting date.

The number of plants expressing tomato yellow leaf curl symptoms was also recorded at different tomato growth stages, i.e. vegetative stage, flowering stage and fruiting stage, per treatment plot. Spread of viral infection was determined in space and time by measuring the distance between old and new infections in relation to the time interval between detection of first symptoms and subsequent symptoms, in the field (Raccah, 1986). At each stage of disease spread, the number of diseased plants was recorded to develop temporal and spatial patterns of diseasespread curves. Disease spread from the first plant infected (single foci) to other plants in space was calculated using Allen's equation (Allen et al., 1983; Plumb and Thresh, 1983), in which distance $\mathrm{x}$ from the first infection source to the new infection is calculated by:

$$
\mathrm{Px}=1-\exp (-\mathrm{x} / \mathrm{x})(7) \text {, }
$$

whereby $\mathrm{x}$ is the mean distance between all new infections and their sources. Spread in time was determined using the formula of Vanderplank, i.e. by:

$\mathrm{dN} / \mathrm{dt}(8)$,

whereby $\mathrm{N}$ is the number of infected plants, $\mathrm{t}$ is the unit of time, $\mathrm{dN}$ is the difference between that number of plants infected, and dt is the difference in time, from when the previously infected plants 
were observed to the currently recorded ones. Using Vanderplank formula (7), the rate at which tomato yellow leaf curl virus (sensu lato) spreads in the field was established.

Mature fruits were harvested weekly, and using a clock weighing scale range of $(1 \mathrm{~g}-10 \mathrm{~kg})$, yield was determined per plot. Note was taken of number of fruits harvested per treatment, total yield, marketable fruit weight and unmarketable fruit weight. Fruits were considered marketable when they had grown to maturity and had neither sign of damage nor rot.

Data were analysed for ANOVA. Linear regression and Pearson correlations were calculated using SAS and SPSS 11.0 statistical programmes. Duncan's Multiple Range Test was also used. Sometimes General Linear Models, Least Square Means Procedure, or square root transformation was used to separate means, in case significant differences were not easy to determine. Means generated were used in Excel to develop related graphs. Standard error values (SE) were used as basis to determine variability within treatment and date effects, while F-distribution values were used to determine significance of differences between those effects (Mead and Curnow, 1990).
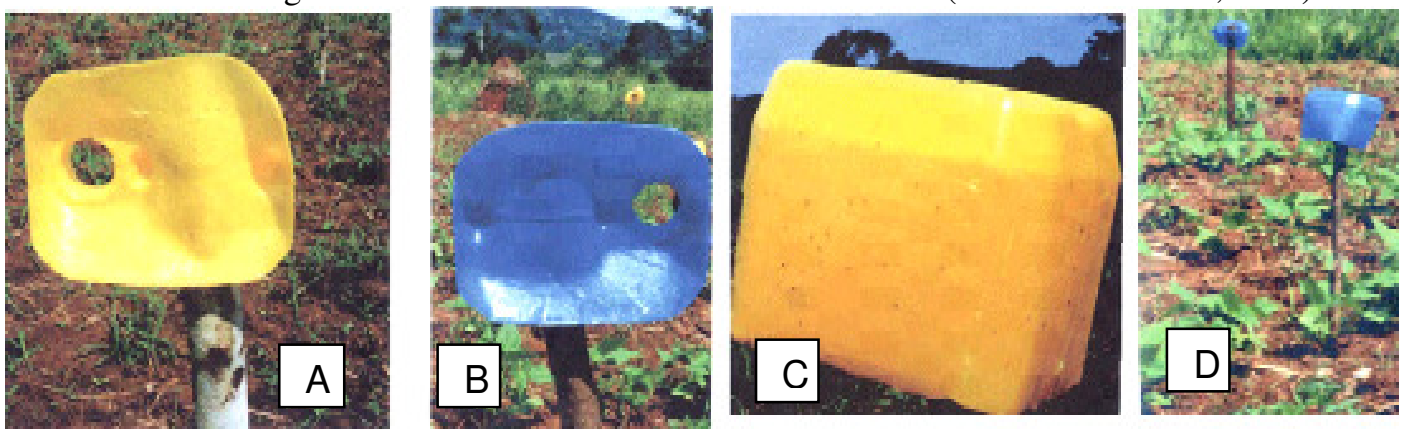

Figure 1: Insect Traps of Yellow and Blue Plastic Material Cut out of Locally Used Containers (A) yellow traps; and (B) blue traps, both of which were cut from the top of a 5 litre plastic jerry can, and with total inner surface area of $0.015 \mathrm{~m}^{2}$ each, which was smeared with Vaseline, and used at corners of treatment plots to trap flying whiteflies. The second set of (C) yellow traps and (D) blue traps were cut from the bottom of a 5 litre plastic jerry can. Each trap had a total surface area of $0.075 \mathrm{~m}^{2}$. These were smeared and located in every centre of treatment plots to trap whiteflies.
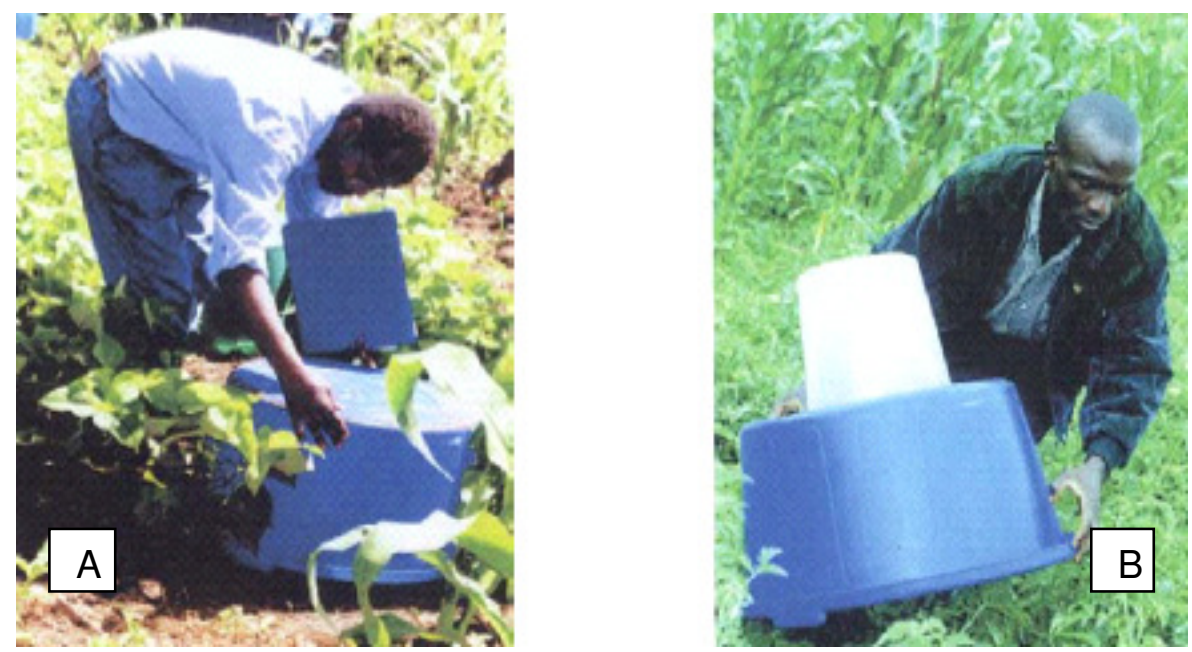

Figure 2: The Kubwa Trap

Note: This was developed from a combination of a plastic basin and a translucent bucket, a new sampling tool made to establish the number of whiteflies on individual tomato plants per plot. The trap has the inner surface area of the translucent part smeared with Vaseline, so that as trapped whiteflies fly towards the light, they stick onto the translucent bucket walls. Figure (A) first design without transparent section; B) improved design with transparent upper part. 


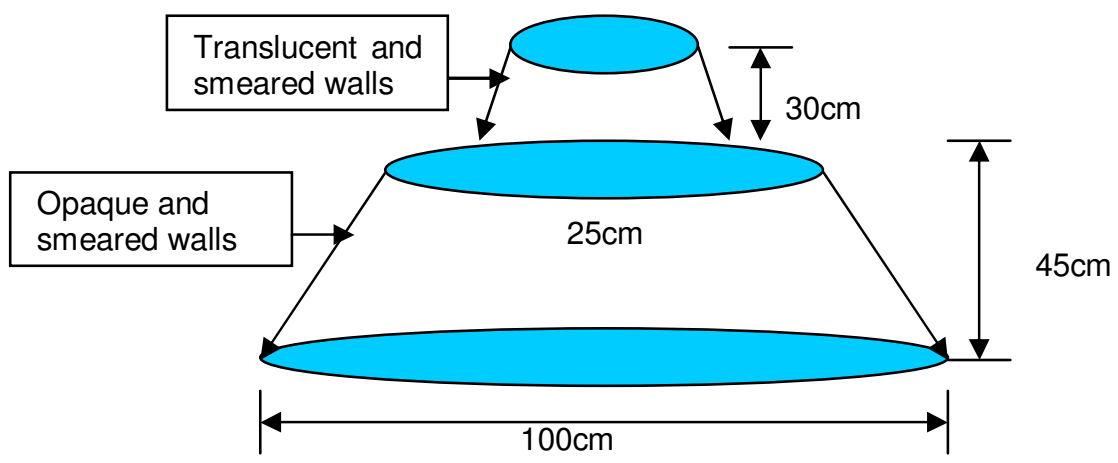

Figure 3: Design of the Kubwa trap, with translucent top part and opaque lower part. This way trapped, when inverted onto a single plant, which is then agitated, whiteflies move towards light in the upper part and they are trapped against the wall smeared with Vaseline.

\section{Results}

In January 1999 there were 8 dry days, whereas in February 1999 there were 22 dry days. In the period January to end of February a mean average rainfall of $9.50 \mathrm{~mm}$ per day and a rainfall range of 0 - $16 \mathrm{~mm}$ per day were recorded. During trial I, March to July 1999, the amount and frequency of rainfall increased with a mean average of $10.14 \mathrm{~mm}$ per day and range of $0-69 \mathrm{~mm}$ per day. There were 37 dry days on a total of 122 days in this period (March to July), with 7 dry days in March, another 7 dry days in April, plus 11 more days in May and finally 12 days in June. During trial II (August to November 1999), there were 59 dry days on a total of 122 days, with a mean average rainfall of $5.70 \mathrm{~mm}$ per day and range of $0-50 \mathrm{~mm}$ per day. In trial III (November to February 2000), there were 51 dry days, of which 22 dry days were in February when the tomato crop had already been harvested. Apart from the period January to February 2000, when maximum temperatures reached a highest peak of $30^{\circ} \mathrm{C}$, for the rest of the first season experiment period average ambient temperatures varied between $20-24{ }^{\circ} \mathrm{C}$. The second season was similar to the first, whereas in the third experimental season average ambient temperatures were $20-26{ }^{\circ} \mathrm{C}$ (Figure 5b).

\section{Whitefly Population Variation and TYLCV Incidence at Different Tomato Growth Stages}

In experimental fields, an inverse relationship was observed between number of whiteflies trapped with sticky traps and number of TYLCV-symptom expressing tomato plants. At the same time, whitefly populations in the field, expressed as number of whiteflies trapped per $\mathrm{m}^{2}$ of the sticky traps, went down as tomato crops grew, i.e. through vegetative, flowering, and fruiting/harvesting stages (Table 1). It was observed that these trends coincided with rainfall patterns. Thus, during the dry season, the whitefly population grew to a maximum average of 119 whiteflies trapped per $\mathrm{m}^{2}$. In the wet season, ten weeks after transplanting, it went down to an average of 10 whiteflies trapped per $\mathrm{m}^{2}$. TYLCV symptoms were more severely visible 5 weeks after whitefly population dropped. As depicted in trial I (Figure 3), temperature was almost constant, and its fluctuation did not seem to either influence whitefly population dynamics or affect TYLCV incidence. Similar trends were observed during trial II (Figure 3) and trial III (Figure 3).

\section{Whitefly Population in the Field and on Individual Plants in Relationship with TYLCV Incidence}

Whitefly populations grew after the first week from 48 whiteflies trapped per $\mathrm{m}^{2}$ to 119 whiteflies trapped per $\mathrm{m}^{2}$ in the second week after transplanting (Table 1). Henceforth, there was a decline in whitefly population in the tomato experimental field throughout the remaining part of the cropping season (21st March to 1st July 1999), i.e. from 119 whiteflies trapped per $\mathrm{m}^{2}$ in the second week (21st to 28th March 1999) to 1 whitefly trapped per $\mathrm{m}^{2}$ in the thirteenth week (16th to 23rd June 1999) after transplanting. In contrast, the number of TYLCV-infected plants per plot went up 
(Table 1) from zero in the second week to 6 infected plants per plot in the thirteenth week. It was observed that whiteflies preferred to feed on young tender tomato to old tomato plants, which could be one of the reasons for the declining whitefly populations. However, TYLCV disease symptoms were clearly expressed only after plants had flowered. A significant negative correlation coefficient of $\mathrm{R}=-0.249, \mathrm{p}=0.005$ was recorded between the whitefly population in the field, which was recorded as number of whiteflies trapped per $\mathrm{m}^{2}$ of sticky traps and number of plants bearing TYLCV symptoms between March and July 1999.

At the same time, a significant negative correlation $(\mathrm{R}=-0183, \mathrm{p}=0.001)$ was observed between number of whiteflies trapped with Kubwa trap per plant per plot and TYLCV incidence (Table 2). Like in the first and second planting (Table 3), in the third planting (Table 4) the number of tomato plants bearing TYLCV symptoms per plot was higher after flowering than during the vegetative growth stage, and the number of whiteflies trapped with Kubwa trap per plant per plot was negatively related with the number of plants bearing TYLCV symptoms $(\mathrm{R}=-0.0597)$. There was a general drop in whitefly population and TYLCV disease incidence along the experiment period (Figure 3). This reduction was related to the increasing number of rain days. The high TYLCV disease incidence and high whitefly population in trial I was due to the prolonged dry period that preceded the establishment of our experiments.

Table 1: Mean Total Whitefly Counts Per $M^{2}$ for Blue and Yellow Traps and Mean Number of TYLCV Infected Plants (Per Plot in Trial I) $(P=0.01$, df $=38, F$ 18, 43; Pearson Correlation of $R$ $=-0.884, P=0.01$ ), Inversely Related

\begin{tabular}{cccc}
\hline Growth stages & $\begin{array}{c}\text { Weeks }^{2} \text { from } \\
\text { transplanting }\end{array}$ & $\begin{array}{c}\text { Ranked mean } \\
\text { whitefly counts } \\
\text { per m }{ }^{2}\end{array}$ & $\begin{array}{c}\text { Ranked mean number of } \\
\text { TYLCV-infected plants, } \\
\text { per plot }\end{array}$ \\
\hline Vegetative stage & 1 & $48 \mathrm{c}$ & $1 \mathrm{~d}$ \\
Flowering stage & 2 & $119 \mathrm{a}$ & $0 \mathrm{~d}$ \\
\hline & & & \\
Harvesting tage & 3 & $89 \mathrm{~b}$ & $3 \mathrm{~d}$ \\
& 4 & $102 \mathrm{ab}$ & $1 \mathrm{~d}$ \\
& 5 & $32 \mathrm{~cd}$ & $4 \mathrm{c}$ \\
& 6 & $13 \mathrm{de}$ & $4 \mathrm{bc}$ \\
& 7 & $7 \mathrm{e}$ & $4 \mathrm{~b}$ \\
& 8 & $6 \mathrm{e}$ & $6 \mathrm{~b}$ \\
& 9 & $13 \mathrm{de}$ & $6 \mathrm{a}$ \\
& 10 & $10 \mathrm{e}$ & $6 \mathrm{a}$ \\
& 11 & $2 \mathrm{e}$ & $6 \mathrm{a}$ \\
& 12 & $1 \mathrm{e}$ & $6 \mathrm{a}$ \\
& 13 & $1 \mathrm{e}$ & $6 \mathrm{a}$ \\
& 14 & $2 \mathrm{e}$ & $6 \mathrm{a}$ \\
& $\mathrm{CV}$ & 0.02 & 0.91 \\
\hline
\end{tabular}

\footnotetext{
${ }^{4}$ Week $1\left(13^{\text {th }}\right.$ to $20^{\text {th }}$ March 1999), Week 2 (21 $1^{\text {th }}$ to $28^{\text {th }}$ March 1999), Week 3 (29* March to $5^{\text {th }}$ April $1999)$, Week 4 ( $6^{\text {th }}$ to $13^{\text {th }}$ April 1999$)$, Week $5\left(14^{\text {te }}\right.$ to $20^{\text {th }}$ April 1999$)$, Week $6\left(21^{\text {th }}\right.$ to $28^{\text {th }}$ April $1999)$, Week 7 (29 April to $5^{\text {th }}$ May 1999), Week 8 (6 $6^{\text {th }}$ to $13^{\text {th }}$ May 1999), Week 9 (14 to $21^{\text {th }}$ May $1999)$, Week $10\left(22^{\text {tad }}\right.$ to $29^{\text {th }}$ May 1999), Week $11\left(30^{\text {th }}\right.$ to $7^{\text {th }}$ Jume 1999$)$, Week 12 ( $8^{\text {th }}$ to $15^{\text {th }}$ June 1999 ), Week 13 ( $16^{\text {th }}$ to $23^{\text {rd }}$ June 1999$)$, Week 14 (24 $4^{\text {th }}$ June to $1^{\text {th }}$ July 1999$)$. Weeks $15-20$ had same trend as 13 and 14 , and were not included in the table

2 Ranking and significance are indicated by letters a-e, whereby different single letters refer to means, which are significantly different, same letters refer to means, which are not significantly different or are statistically the same
} 


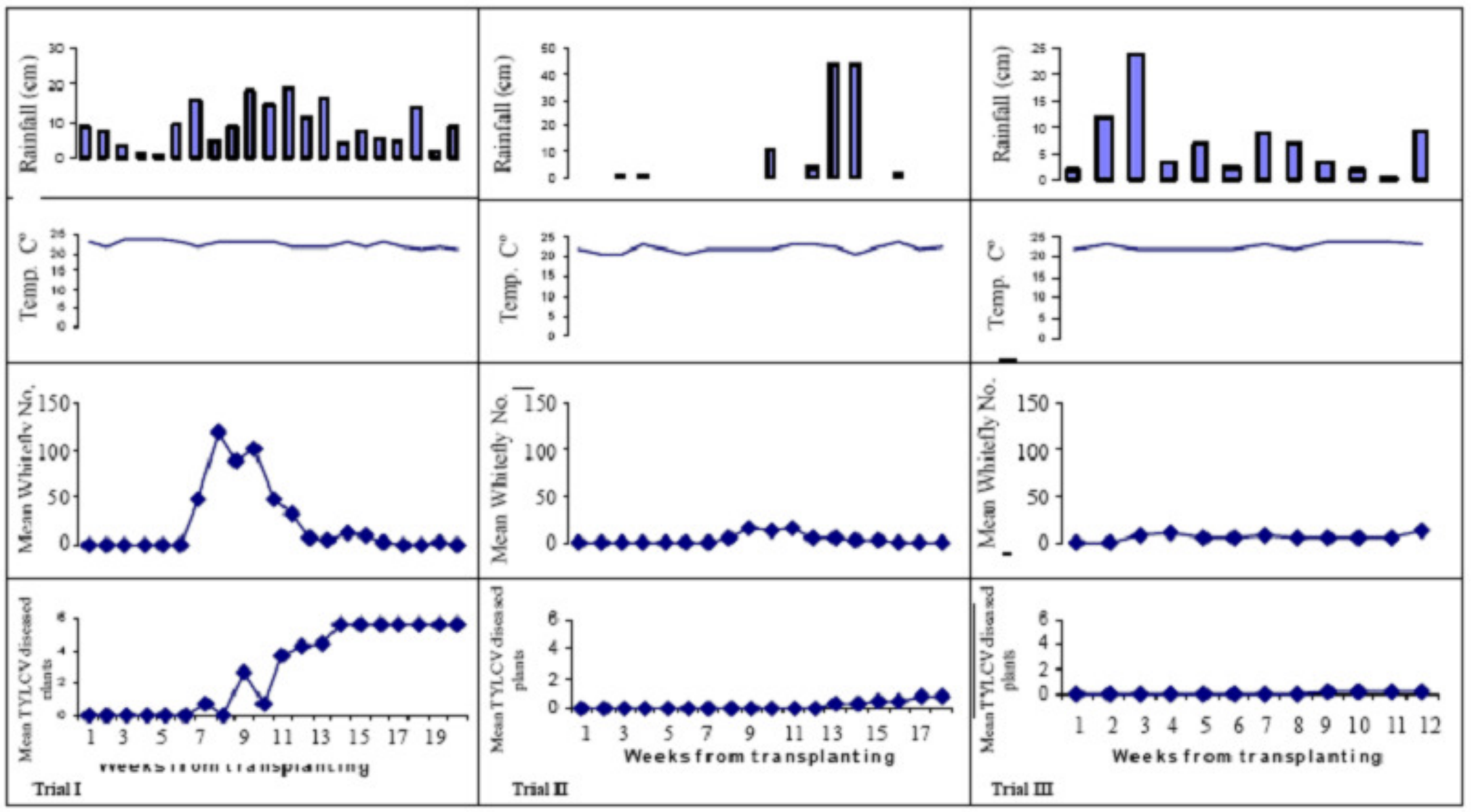

Figure 3: Reducing Whitefly and TYLCV Levels from Trial I to III

Note: Reducing Whitefly and TYLCV diseases levels from trial I to III Due to crop maturity, and increasing number of rainy days, an evidence of random extinction (Garcia-Arenal et al., 2000). Trial I with high levels of whitefly population and TYLCV disease incidence was preceded by a prolonged dry season. 
Table 2: Ranked mean weekly number of whiteflies trapped per plant per plot with Kubwa trap and related ranked mean weekly number of TYLCV symptom-bearing plants in trial I (F18, 20; $d f=13, p=0.05$ ) (March to July 1999). Inverse relationship

\begin{tabular}{ccc}
\hline $\begin{array}{l}\text { Weeks from } \\
\text { transplanting }\end{array}$ & $\begin{array}{c}\text { Ranked }{ }^{4} \text { mean whitefly } \\
\text { count per plot }\end{array}$ & $\begin{array}{l}\text { Ranked mean number of TYLCV- } \\
\text { infected plants }\end{array}$ \\
\hline 1 & $88 \mathrm{a}$ & $3 \mathrm{c}$ \\
2 & $25 \mathrm{~b}$ & $4 \mathrm{~b}$ \\
3 & $14 \mathrm{~cd}$ & $4 \mathrm{~b}$ \\
4 & $8 \mathrm{de}$ & $4 \mathrm{~b}$ \\
5 & $18 \mathrm{bc}$ & $5 \mathrm{a}$ \\
6 & $8 \mathrm{e}$ & $5 \mathrm{a}$ \\
7 & $4 \mathrm{e}$ & $5 \mathrm{a}$ \\
& & \\
\hline $\mathrm{SE}$ & 0.03 & 0.57 \\
$\mathrm{CV}$ & 0.02 & 0.91 \\
\hline
\end{tabular}

${ }^{1}$ Ranking is indicated by letters a-e, whereby for example (a) or (b) refers to means, which are significantly different, whereas ( $\mathrm{ab}, \mathrm{cd}$, de, and $\mathrm{bc}$ ) refer to means that statistically have no significant deference between them. Values with same letter are statistically the same.

Table 3: Ranked mean weekly number of whiteflies trapped per plant per plot with Kubwa trap in relation to ranked mean weekly number of TYLCV symptom-bearing plants $(F 18,20 ; d f=13$; $p=0.001$ ) during trial II (August to November, 1999). Inverse relationship.

\begin{tabular}{|c|c|c|}
\hline $\begin{array}{l}\text { Weeks from } \\
\text { transplanting }\end{array}$ & $\begin{array}{l}\text { Ranked'mean whitefly count } \\
\text { per plot }\end{array}$ & $\begin{array}{l}\text { Ranked }{ }^{1} \text { mean TYLCV- } \\
\text { infection }\end{array}$ \\
\hline 1 & $1.7 \mathrm{de}$ & $0.0 \mathrm{c}$ \\
\hline 2 & $5.0 \mathrm{a}$ & $0.0 \mathrm{c}$ \\
\hline 3 & $4.0 \mathrm{ab}$ & $0.0 \mathrm{c}$ \\
\hline 4 & $2.9 \mathrm{bc}$ & $0.0 \mathrm{c}$ \\
\hline 5 & $2.8 \mathrm{~cd}$ & $0.0 \mathrm{c}$ \\
\hline 6 & $1.7 \mathrm{de}$ & $0.0 \mathrm{c}$ \\
\hline 7 & 1.2ef & $0.25 \mathrm{~b}$ \\
\hline 8 & $0.6 \mathrm{ef}$ & $0.39 \mathrm{ab}$ \\
\hline 9 & $0.4 \mathrm{f}$ & $0.4 \mathrm{a}$ \\
\hline $\mathrm{SE}$ & 0.30 & 0.57 \\
\hline $\mathrm{CV}$ & 0.02 & 0.91 \\
\hline
\end{tabular}

${ }^{1}$ Ranking is indicated by letters a-f, whereby (a) or (b) refers to means, which are significantly different, whereas ( $a b, c d, d e, b c$, and ef) refer to means that statistically have no significant defference between them. Values with same letter ranking are statistically the same. 
Table 4: Ranked mean weekly number of whiteflies trapped per plant per plot with Kubwa trap ( $f$ 1.25, $p$ 0.0001) in relation to ranked mean weekly number of TYLCV symptom bearing plants ( $F$ 18,20; df = 13; $p=0.001)$ in trial III, (November 1999 to February 2000)

\begin{tabular}{ccc}
\hline $\begin{array}{l}\text { Weeks from } \\
\text { transplanting }\end{array}$ & $\begin{array}{l}\text { Ranked }^{1} \text { mean whitefly } \\
\text { count per plot }\end{array}$ & $\begin{array}{l}\text { Ranked mean number TYLCV infected } \\
\text { plants }\end{array}$ \\
\hline 1 & $3.7 \mathrm{bc}$ & $0 \mathrm{c}$ \\
2 & $7.4 \mathrm{a}$ & $0 \mathrm{c}$ \\
3 & $1.5 \mathrm{bc}$ & $0 \mathrm{c}$ \\
4 & $5.3 \mathrm{ab}$ & $0 \mathrm{c}$ \\
5 & $4.3 \mathrm{ab}$ & $0 \mathrm{c}$ \\
6 & $3.3 \mathrm{bc}$ & $0.1 \mathrm{a}$ \\
7 & $0.4 \mathrm{c}$ & $0.3 \mathrm{~b}$ \\
8 & $1.8 \mathrm{bc}$ & $0.3 \mathrm{~b}$ \\
9 & $1.6 \mathrm{bc}$ & $0.3 \mathrm{~b}$ \\
& & \\
\hline $\mathrm{SE}$ & 0.03 & 0.57 \\
$\mathrm{CV}$ & 0.02 & 0.91 \\
\hline
\end{tabular}

${ }^{1}$ Ranking is indicated by letters a-c, whereby (a), (b) or (c) refers to means, which are significantly different, whereas ( $a b$ and $b c$ ) refer to means that statistically have no significant difference between them. Values with same letter ranking are statistically not different.

\section{Treatment-specific Whitefly Infestation and TYLCV Incidence}

With regard to the different treatment effects on whitefly infestation of tomato plants monitored using the Kubwa trap, there was no significant treatment effect on whitefly population in trial I, though plots with tomato-bean intercrop without insecticide application and those with tomato-bean intercrop combined with dimethoate had fewer whiteflies than tomato monocrop, tomato monocrop combined with uprooting, tomato monocrop combined with dimethoate, and tomato monocrop combined with uprooting and dimethoate. It was not clear whether Phaseolus beans in intercrop treatments could have acted as a whitefly trap crop in Trial I, II and III (Table 5), in which case beans would be preferred to tomato. Furthermore, during the first week after treatment application, whitefly populations in all treatments fell to a lower level than the one recorded at the start, except in plots where tomato was intercropped with beans and bean rows were sprayed with dimethoate, in which case whitefly populations rose but later dropped like in other plots. All treatments maintained whitefly populations below three whiteflies per tomato plant one week after treatment application. Because of persistent TYLCV transmission by whiteflies, even one whitefly would be enough to raise concern.

Uprooting TYLCV-infected plants and dimethoate application treatment were able to contain whitefly populations at the lowest level throughout the experimental season, albeit with minimal difference from plots treated with tomato-bean intercrop plus spraying bean rows with dimethoate (Figure 4). This situation could be explained by the fact that by uprooting TYLCV disease symptom-bearing plants (single foci), which are sources of inoculum, secondary infection or polycyclic disease epidemic is eliminated. It was noted that the first planting was preceded by a very dry season, which favoured whitefly population growth, as also observed by Mazyad et al. (1979) and reported by Henneberry and Castle (2001). It is also worth noting that March to July rains are usually heavier than August to December rains. 
Table 5: Mean number of whiteflies trapped by Kubwa trap per plant per plot in trial I, II and III (df = 13; F 18, 20; p = 0.001)

\begin{tabular}{|c|c|c|c|c|c|}
\hline \multicolumn{2}{|l|}{ Trial I (March- July 1999) } & \multirow{2}{*}{$\begin{array}{l}\text { Trial II (August - Nov. 1999) } \\
\text { Ranked treatments }\end{array}$} & \multirow[b]{2}{*}{$\begin{array}{l}\text { Whitefly mean } \\
\text { count per plot }\end{array}$} & \multicolumn{2}{|l|}{ Trial III ( Nov. 1999 - Feb. 2000) } \\
\hline Ranked treatments & $\begin{array}{l}\text { Whitefly mean } \\
\text { count per plot }\end{array}$ & & & Ranked treatments & $\begin{array}{l}\text { Whitefly } \\
\text { mean } \\
\text { count per } \\
\text { plot }\end{array}$ \\
\hline Tomato monocrop $\mathrm{x}$ uprooting & 29 & Tomato monocrop $\mathrm{x}$ uprooting & 0.23 & Intercrop $\mathrm{x}$ dimethoate on beans & 0.21 \\
\hline Tomato monocrop & 27 & Monocrop $\mathrm{x}$ dimethoate & 0.17 & Monocrop x dimethoate & 0.20 \\
\hline Monocrop $\mathrm{x}$ dimethoate & 23 & Intercrop $\mathrm{x}$ dimethoate on beans & 0.17 & Tomato monocrop $\mathrm{x}$ uprooting & 0.18 \\
\hline Monocrop $\mathrm{x}$ uproot $\mathrm{x}$ dimethoate & 22 & Tomato monocrop & 0.11 & Tomato monocrop & 0.18 \\
\hline Tomato-beans intercrop & 20 & Tomato-beans intercrop & 0.04 & Monocrop $\mathrm{x}$ uproot $\mathrm{x}$ dimethoate & 0.18 \\
\hline Intercrop $\mathrm{x}$ dimethoate on beans & 20 & Monocrop $\mathrm{x}$ uproot $\mathrm{x}$ dimethoate & 0.02 & Tomato-beans intercrop & 0.16 \\
\hline $\mathrm{SE}$ & 0.30 & & 0.30 & & 0.30 \\
\hline $\mathrm{CV}$ & 0.02 & & 0.02 & & 0.02 \\
\hline
\end{tabular}



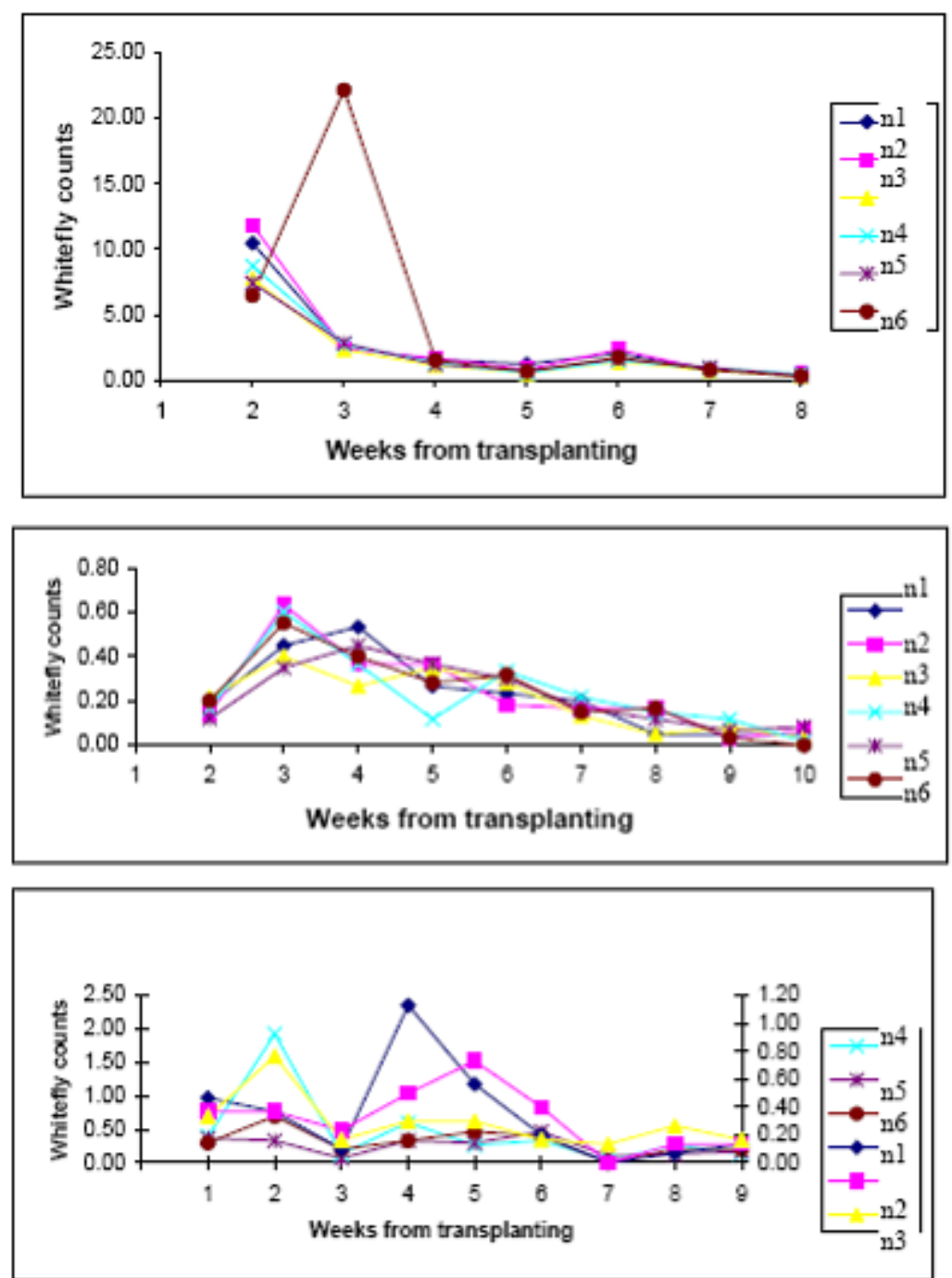

Figure 4: Mean whitefly counts within the three trials (1999 to 2000)

For trial II (Figure 4), the trend was indicative of more favourable conditions for whitefly infestation. As such, treatment effect was noticeable after the second week. Furthermore, a less precise trend was observed in trial III (Figure 4) with limited treatment effects on whitefly populations, which could have been due to more frequent rainfall, as evidenced in Figure 3. However, within the first six weeks of November 1999 to February 2000 experimental period, whitefly populations rose drastically at two incidences, especially for the control monocrop. For monocrop plots 4 and 5 sprayed with dimethoate, the rise in whitefly populations was evident between the third to the sixth week, a situation similar to what is expected to happen when natural enemies are killed or when pests develop resistance to pesticides, but also the attractive vegetative nature of tomato plants at this stage. A similar trend was also observed, to a lesser degree, in plots where uprooting and dimethoate were applied, as well as in those with tomato-bean intercrop where bean rows were sprayed with dimethoate insecticide. 


\section{Tomato yellow leaf curl virus (sensu lato) Incidence and Spread under Different Experimental Treatments}

Taking all three trials, i.e. I (March-July 1999), II (August - Nov.1999), and III (Nov.1999 February 2000), there was less TYLCV disease incidence in trial II and III than in trial I due to a dual effect consisting of treatment effects (n1-n6) in Figure 5, and weather changes, as shown also in figure 6. Thus, during trial I (Figure 5), disease progress curves with sigmoid-like pattern were observed for all treatment plots except for plots with tomato-bean intercrop and no dimethoate application (n3), which produced a pattern characteristic of a monocyclic disease spread (Thresh, 1998). A monocyclic disease starts off with a direct increase in number of infected plants over time, but gradually slows down and stabilizes at a certain level without rising again. From the results, it was clear that uprooting combined with dimethoate (n5), which had a significantly low disease incidence curve (Figure 5), was the most effective in controlling TYLCV. The same treatment (n5) also had low disease incidence in August to November 1999 (trial II) as shown in Figure 5

Thus, this treatment delayed TYLCV disease onset until the 8th week, when disease incidence increased. However, the tomato crop was 8 weeks old when harvesting was carried out in the second week. During the same planting season, the tomato-bean intercrop was also effective in controlling TYLCV, but the first diseased plants occurred a week earlier than in plots where uprooting and dimethoate was applied. As in trial I, the tomato-bean intercrop with a dimethoate application only on bean rows had highest TYLCV incidence, and was therefore the least effective. Plots with uprooting only (n2) and those with a monocrop sprayed with dimethoate (n4) performed worse than the control (n1). In trial III (Figure 5) and after the 7th week, uprooting with dimethoate application (n5) had similar effects to those with application of dimethoate only (n4). However, in plots where only uprooting was practiced (n2), the disease was contained at zero, and therefore would serve as the best environment-friendly option to continue with after the seventh week. This time, the tomato-bean intercrop with dimethoate sprayed on bean rows had no visible TYLCV disease symptoms, basically because there was a severe outbreak of late blight disease (due to heavy rainfall in November 1999). The latter blight probably masked TYLCV symptoms if there were any. Data collection was stopped at either the 7th or 9th week because thereafter there were no more noticeable changes, and the crop was at harvesting stages.

Uprooting and dimethoate application plots (n5) had longest mean distances between TYLCVinfected plants while the tomato-beans intercrop (n3) had shortest mean distances (Table 6). Calculated probabilities for the virus to spread from the initial source to a host $25 \mathrm{~m}$ away indicated that all treatments had the same results. There was also evidence of scattered foci of infected tomato plants in all plots.

Considering overall spread of TYLCV in time, calculated following Vanderplank's formula, the highest infection rate occurred in plots where the tomato monocrop and dimethoate were applied. Lowest infection rate of 0.032 was recorded in plots where uprooting and dimethoate were applied as indicated in table 7. It was established that there was no significant difference between plots with a tomato-bean intercrop with an infection rate of 0.056 and those with tomato-bean intercrop bean rows sprayed with dimethoate $(\mathrm{n} 3)$ with an infection rate of 0.053 . The latter was also similar to that of plots with only a tomato monocrop (n1), which was also the control (0.053), and were, therefore, not cost-effective. At the same time, uprooting alone with an infection rate of 0.049 yielded non-significant differences from the control. 
Table 6: Mean distance from initial infection to secondary infected plants throughout the cropping year (March 1999 to February 2000), calculated according to Allen (Plumb and Thresh, 1983)

\begin{tabular}{l|c}
\hline Treatments & Ranked: Mean distance (cm) \\
\hline Monocrop x uprooting x dimethoate (n5) & $273 \mathrm{a}$ \\
Monocrop x uprooting (n2) & $239 \mathrm{ab}$ \\
Tomato monocrop (n1) & $230 \mathrm{ab}$ \\
Intercrop x dimethoate on beans (n6) & $210 \mathrm{ab}$ \\
Monocrop x dimethoate (n4) & $173 \mathrm{ab}$ \\
Tomato - bean intercrop (n3) & $142 \mathrm{~b}$ \\
\hline
\end{tabular}

${ }^{1}$ Ranking is indicated by letters $\mathbf{a}$ and $\mathbf{b}$, whereby (a), or (b) refers to means, which are significantly different, whereas (ab) refer to means that statistically have no significant difference

Table 7: Infection rate for the different experiment plots for the period March 1999 to February 2000, calculated according to Vanderplank formula (dN/dt) Treatments Ranked'annual mean infection rate $(\mathrm{dN} / \mathrm{dt})$

\begin{tabular}{l|l}
\hline Treatments & $\begin{array}{l}\text { Ranked'annual mean infection rate } \\
(\mathrm{dN} / \mathrm{dt})\end{array}$ \\
\hline Monocrop x dimethoate (n4) & $0.074 \mathrm{a}$ \\
Intercrop x dimethoate on beans (n6) & $0.056 \mathrm{ab}$ \\
Tomato - beans intercrop (n3) & $0.053 \mathrm{ab}$ \\
Tomato monocrop (n1) & $0.053 \mathrm{ab}$ \\
Monocrop x uprooting (n2) & $0.049 \mathrm{ab}$ \\
Monocrop x uprooting x dimethoate (n5) & $0.032 \mathrm{~b}$ \\
\hline
\end{tabular}

${ }^{1}$ Ranking is indicated by letters $a$ and $b$, whereby (a), or (b) refers to means, which are significantly different, whereas (ab) refer to means that statistically have no significant difference 

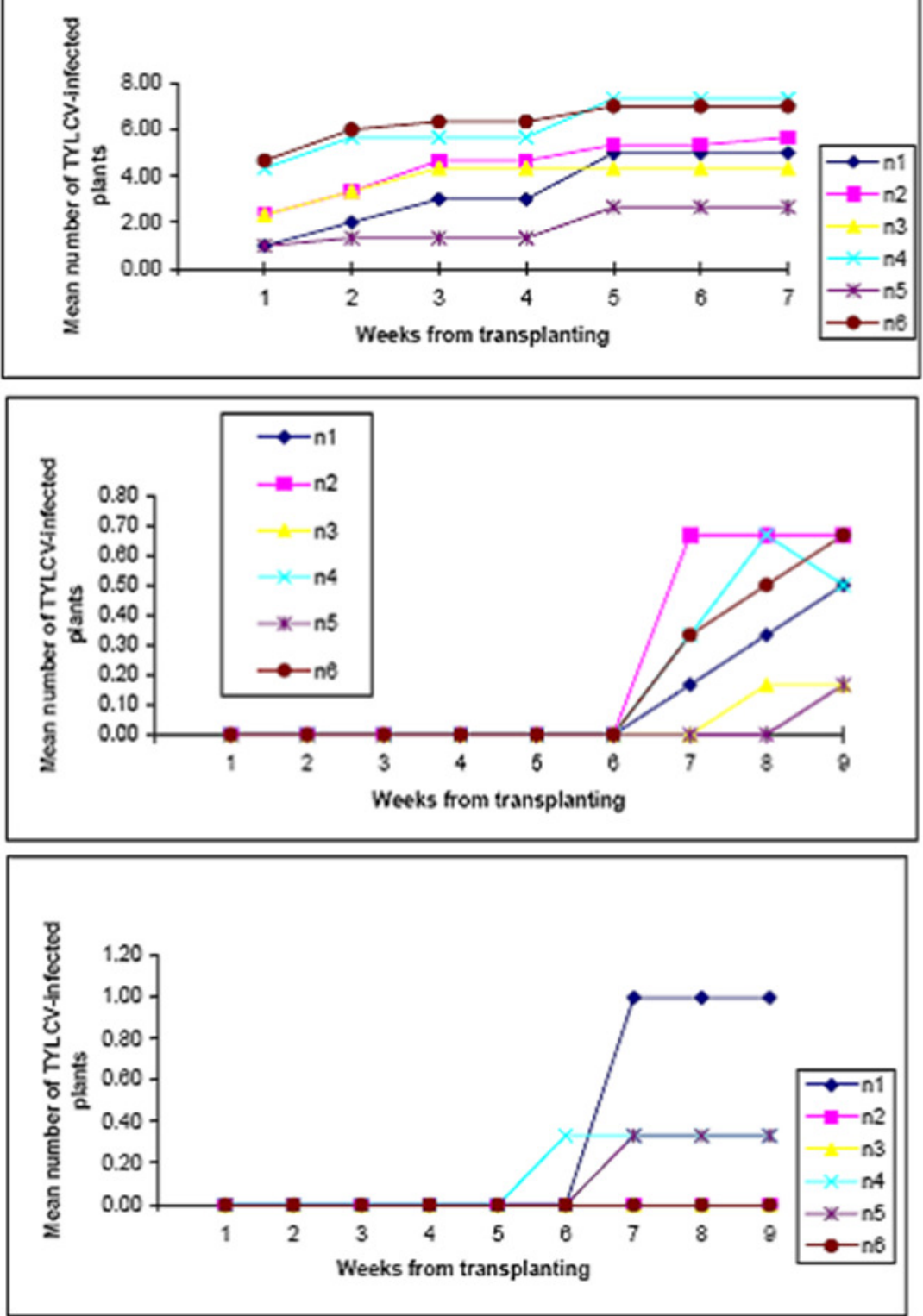

Figure 5: TYLCV disease progress curves for each treatment (n1- n6) in the three trials from 1999 to 2000 


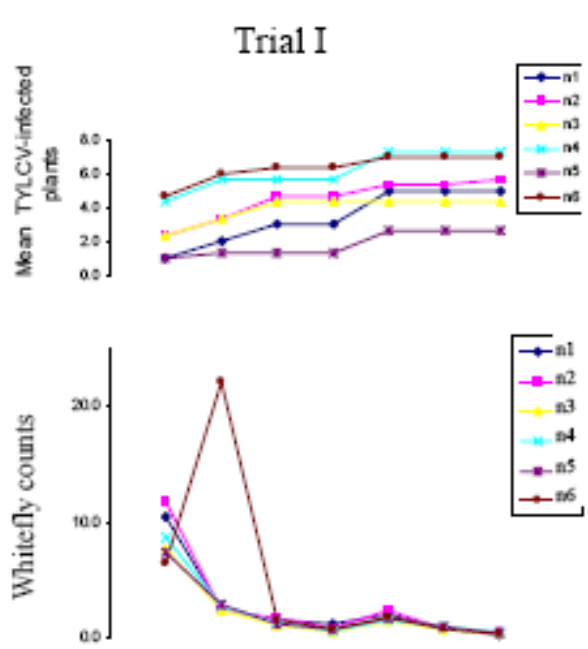

Trial II
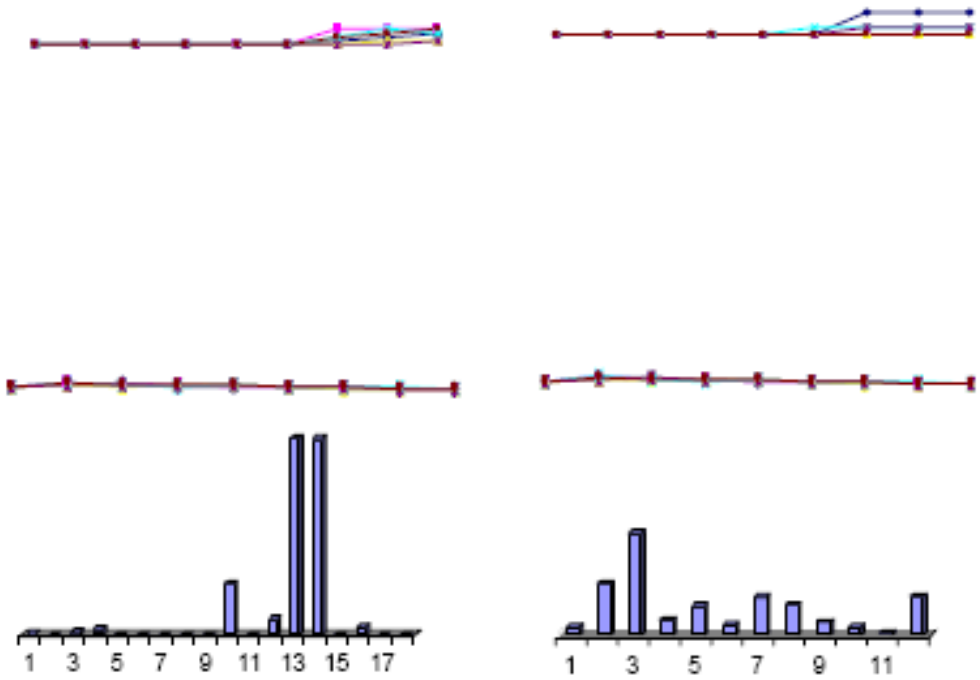

Weeks from transplanting
Trial III

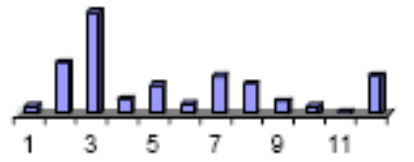

Weeks from transplanting

Figure 6: Treatment effects on incidence of TYLCV diseases and whitefly infestation of tomato plants in the three trials, i.e. Trial I, Trial 2 and Trial 3 , in relation to rainfall. Like in the general study of whitefly population dynamics in the tomato agro-ecosystem (sections 20.1.1 and 20.1.2), rainfall frequency during the experimental period reduced both number of whitefly on tomato plants and number of TYLCV diseased plants in individual treatments. However, being that whiteflies transmit TYLCV in a persistent manner, even one whitefly in the field is of paramount importance. Similarly, a single focus of TYLCV disease is a potential source of inoculum for other plants to be infected, and it is significant when few infected plants represent scattered foci from where the disease can be transmitted to other plants, not to mention the role played by alternative hosts. 


\section{Treatment Effect on Tomato Productivity}

Tomato yield differed between treatments in trial I. Tomato monocrop combined with dimethoate application (n4), and uprooting combined with dimethoate (n5) had the biggest number of fruits harvested. However, uprooting combined with dimethoate (n5) had low TYLCV infection. At the same time, bean-tomato intercrop with dimethoate sprayed only on beans (n6) had lowest number of tomato fruits (Table 8). The control treatment with only a tomato monocrop (n1) had more fruits than plots where uprooting was applied, and those with tomato-bean intercrop. Total yield and marketable yield results were directly related to number of fruits harvested as evidenced in table 8 .

Taking the number of tomato fruits produced per treatment in trial II, a trend similar to that observed in trial I was noted. Tomato monocrop combined with dimethoate plots (n4) and those with uprooting combined with dimethoate (n5) had the biggest number of fruits. They were also significantly different from monocrop plots with uprooting (n2), plots with tomato-bean intercrop (n3), and from those plots with tomato-beans intercrop combined with dimethoate (n6). Furthermore, tomato-beans intercrop with dimethoate applied on bean rows alone (n6), which had lowest number of fruits (Table 8), was also found to have the highest number of plants infected with TYLCV. This implied that intercropping with beans does not reduce TYLCV infection. TYLCV is transmitted in a persistent manner. Therefore and if at all, beans attracting whiteflies to the intercrop plot could have exposed tomato plants to more chances of infection from even short interval feeding by TYLCV inoculum-bearing whiteflies. Uprooting with dimethoate was therefore still the most effective treatment, while uprooting, tomato-bean intercrop and tomato-bean intercrop combined with dimethoate, which gave yields lower than that of control plots, were not effective.

Apart from tomato-bean intercrop combined with dimethoate on beans only (n6), all dimethoatetreated plots had on average better total yields than those without. Thus, $\mathrm{n} 4$ had total yield of 5.7 $\mathrm{kgs}$ in trial I, $14.8 \mathrm{kgs}$ in trial II, and $1.6 \mathrm{kgs}$ in trial III, while $\mathrm{n} 5 \mathrm{had} 4.9 \mathrm{kgs}, 14.8 \mathrm{kgs}$, and $1.1 \mathrm{~kg}$ respectively, as indicated in table 8 . In terms of weight and marketable quality, tomato monocrop combined with dimethoate (n4), uprooting combined with dimethoate (n5), and tomato-bean intercrop with dimethoate on bean rows only (n6), still performed better than those plots without dimethoate treatment. At the same time, plots with tomato-bean intercrop combined with dimethoate on bean rows (n6) had few, but heavy and market-quality fruits. Uprooting alone gave better results than the control, even though the difference was not significant. The bean-tomato intercrop without dimethoate (n3) performed worst. There was also a negative relationship of $\mathrm{R}=-$ $0.1438, \mathrm{p}=0.0402$ between number of plants infected with TYLCV and percentage marketable yield.

Yield results in trial III were different from those in trials I, and II. Thus, there was no significant difference between fruit numbers per treatment (Table 8). Data on fruit weights indicated that intercropping tomato with beans and applying dimethoate on bean rows (n6) gave lowest total yield followed by uprooting combined with dimethoate (n5), which was not significantly different from either control (n1), uprooting alone (n2), tomato-bean intercrop (n3), and tomato monocrop combined with dimethoate $(\mathrm{n} 4)$. For marketable yield, the tomato-bean intercrop combined with dimethoate (n6) had the lowest marketable yield followed by uprooting alone (n2). 
Table 8: Ranked (a-c) ${ }^{1}$ mean number of fruits, total yield and marketable yield $(\mathrm{kg})$ for three replicate plots put together $\left(90 \mathrm{~m}^{2}\right)$, for each treatment in trials $\mathrm{I}$, II and III

\begin{tabular}{|c|c|c|c|c|c|c|c|c|c|}
\hline \multirow[t]{2}{*}{ Treatments } & \multicolumn{3}{|c|}{ Trial I (March - July, 1999) } & \multicolumn{3}{|c|}{ Trial II (Aug. - Nov. 1999) } & \multicolumn{3}{|c|}{$\begin{array}{l}\text { Trial III } \\
\text { (Nov. 1999 - Feb. 2000) }\end{array}$} \\
\hline & $\begin{array}{l}\text { Number } \\
\text { of fruits } \\
\text { per plot }\end{array}$ & $\begin{array}{l}\text { Total } \\
\text { yield } \\
(\mathrm{kg})\end{array}$ & $\begin{array}{l}\text { Marketable } \\
\text { yield } \\
(\mathrm{kg})\end{array}$ & $\begin{array}{l}\text { Number of } \\
\text { fruits per } \\
\text { plot }\end{array}$ & $\begin{array}{l}\text { Total } \\
\text { yield } \\
(\mathrm{kg})\end{array}$ & $\begin{array}{l}\text { Marketable } \\
\text { yield }(\mathrm{kg})\end{array}$ & $\begin{array}{l}\text { Number } \\
\text { of fruits } \\
\text { per plot }\end{array}$ & $\begin{array}{l}\text { Total } \\
\text { yield } \\
(\mathrm{kg})\end{array}$ & $\begin{array}{l}\text { Marketable } \\
\text { yield } \\
(\mathrm{kg})\end{array}$ \\
\hline 1-Monocrop control & $73 \mathrm{ab}$ & $4.1 \mathrm{ab}$ & $3.6 \mathrm{ab}$ & $119 \mathrm{~b}$ & $10.8 \mathrm{bc}$ & $10.7 \mathrm{ab}$ & $26 a$ & $1.5 \mathrm{a}$ & $1.2 \mathrm{a}$ \\
\hline 2-Uprooting & $59 \mathrm{bc}$ & $3.5 \mathrm{bc}$ & $3.2 \mathrm{ab}$ & $119 \mathrm{~b}$ & $12.2 \mathrm{~b}$ & $11.4 \mathrm{ab}$ & $24 a$ & $1.6 \mathrm{a}$ & $0.59 \mathrm{~b}$ \\
\hline 3-Tomato/beans intercrop & $40 \mathrm{c}$ & $2.2 \mathrm{c}$ & $1.9 \mathrm{c}$ & $106 \mathrm{c}$ & $10.1 b c$ & $9.5 \mathrm{c}$ & $26 a$ & $1.9 \mathrm{a}$ & $1.6 \mathrm{a}$ \\
\hline 4-Monocrop and Dimethoate & $93 a$ & $5.7 \mathrm{a}$ & $5.1 \mathrm{a}$ & $139 a$ & $14.8 \mathrm{a}$ & $13.9 \mathrm{a}$ & $24 a$ & $1.6 \mathrm{a}$ & $1.4 a$ \\
\hline 5-Uprooting and Dimethoate & $89 a$ & $4.9 \mathrm{ab}$ & $4.6 \mathrm{ab}$ & $142 a$ & $14.8 \mathrm{a}$ & $13.7 \mathrm{a}$ & $21 \mathrm{a}$ & $1.1 \mathrm{ab}$ & $0.8 \mathrm{ab}$ \\
\hline $\begin{array}{l}\text { 6-Tomato/beans intercrop and } \\
\text { dimethoate on beans only }\end{array}$ & $34 \mathrm{c}$ & $1.9 \mathrm{c}$ & $1.7 \mathrm{c}$ & $112 \mathrm{bc}$ & $14.5 \mathrm{a}$ & $13.7 \mathrm{a}$ & $11 \mathrm{~b}$ & $0.5 \mathrm{~b}$ & $0.5 \mathrm{~b}$ \\
\hline MSE & 2.8 & 9.9 & 9.9 & 57.9 & 7.6 & 7.2 & 28.5 & 1.5 & 1.2 \\
\hline
\end{tabular}

' Ranking is indicated by letters a-c, whereby (a), (b) or (c) refers to means, which are significantly different, whereas (ab and bc) refers to means that statistically have no significant difference 


\section{Discussion}

The study confirmed that weather changes influence whitefly population dynamics and TYLCV incidence in Uganda. It was also confirmed that whatever the weather condition, whitefly infestation was more common on young tomato plants with fresh and soft leaves than on old tomato plants. However, it was observed that TYLCV symptoms were visible at an advanced stage of tomato growth, except for cases of very early seedling infection, quasi-primary infection. Experiments were replicated during wet and dry seasons to take care of natural conditions like rainfall and temperature, which affected our trials in addition to experimental treatments. Riley et al. (1995) and Elkiton (1993) observed the effect of climatic factors on whitefly populations and specifically reported rainfall, relative humidity, temperature and wind to induce increase or reduction in whitefly populations. However, during our study temperature was almost constant throughout the year, whereas rainy weather conditions varied and also caused a fall in whitefly populations (Figures 4). Thus, in May to June and October to December rainy seasons, which were associated with severe TYLCV symptoms, whitefly populations were low (Figures 4). Because of the bi-modal pattern of rainfall, two periods of low whitefly populations occurred in alternation with high whitefly population periods. Moustafa (1991) found similar weather effects on TYLCV incidence and on whitefly populations in Egypt. He reported low TYLCV incidence in Spring and early Summer (February to April) and high incidence at the end of Summer (September to midOctober). In Tanzania, Nono-Womdim et al. (1996) reported TYLCV disease symptoms and a high whitefly population to occur at the same time, i.e. from November to February. This situation differs from that found in Uganda probably because of irrigated tomato production that takes place most of the year, especially in Arusha region of Tanzania. Likewise our findings were contrary to Mansour et al. (1992) and Mehta et al. (1994) reports, which indicate that high incidence of TYLCV coincides with high whitefly populations. The latter authors together with Cohen and Antignus (1994) reported that TYLCV occurrence and spread are directly proportional to whitefly populations. We, however, found that there was a time lag of 3-4 weeks between first observation of whiteflies on tomato and symptom expression. As a result, there are more TYLCV (sensu lato) disease symptoms recorded on old tomato plants than on young plants during the wet season (Table 5.1).

Furthermore, it was established that TYLCV disease seems to spread in a monocyclic manner. In this pattern, tomato plants are infected without subsequent spread of the disease. Our study also showed presence of scattered foci of infected tomato plants, i.e. isolated diseased plants, in all treatments (Table 5.6). It was not possible to establish whether these new infections are due to whiteflies coming in from outside (external host to tomato) or by whiteflies moving from one infected tomato plant to another within the field (tomato to tomato disease spread), which would then result into a polycyclic disease spread pattern. To manage TYLCV diseases, timely planting is considered a potential solution based on response to weather changes by whitefly vector populations and TYLCV symptom expression, as mentioned above. Sticky Vaseline traps showed higher whitefly populations in the young vegetative crop followed by the flowering crop, whereas few were trapped from the crop at harvesting stage (Table 5.1 and Figures 5.3c, 5.4c, 5.5c). This result implies that early application of uprooting combined with dimethoate (n5) is most effective for both whitefly management and TYLCV control. The combination was better than either uprooting or dimethoate application alone, especially in trial II, as shown in table 5.5 and figures 5 . Perring et al. (1999) reported that integrated virus control was more effective than applying one option. Brown (1997)'s review explained that whiteflies multiply faster on TYLCV infected plants. This being true, uprooting is advantageous because it deprives whiteflies of the suitable environment for rapid multiplication.

Experimental treatments with a bean intercrop produced very low tomato fruit yields, and yet had low whitefly population. Investigation of other causes was beyond the scope of this study, but it requires future consideration as to whether there is competition for nutrients between these two 
crops. At the same time, non-significant differences between treatments (n1, n3, n4 and n6) in trials I -III were recorded, and this was attributed to such factors as prevailing winds and alternative hosts, which may have influenced whitefly population in all treatments, and hence affected TYLCV incidence as well as general treatment performance.

More whiteflies were observed on the bean crop than on tomato within the intercrop. This way the bean intercrop was considered able to influence whitefly population dynamics by acting as a trap crop, the so-called "pull effect". In treatment 6 (Table 5.5), beans attracted whiteflies whereas dimethoate was applied to kill attracted whiteflies. This can be termed a pull and kill method, but it was not significantly effective in reducing whitefly populations. Application of dimethoate on beans may also have repelled whiteflies from beans to unsprayed tomato rows. This would explain the high number of whiteflies trapped on individual tomato plants using Kubwa trap in this treatment (Table 5.5). A similar situation may arise when farmers apply pesticides on their tomatoes, thus causing whiteflies to migrate from sprayed to unsprayed hosts in the complex agroecosystem.

Furthermore, spraying a tomato monocrop with dimethoate insecticide, which is a broadspectrum and systemic insecticide, is similar to the situation in Ugandan farmers' fields, where continuous application of various pesticides takes place. A monocrop sprayed with dimethoate (n4) performed worse than the control plot (n1). Continuous application of such insecticides may be leading to eradication of whitefly natural enemies (Henneberry and Castle, 2001; Riley et al., 1995; Duffus, 1995). Uprooting alone (n2) gave better results than where dimethoate was applied (n4) without uprooting diseased plants. Uprooting is a better option if farmers are to manage TYLCV disease, but avoid destroying whitefly natural enemies. Therefore, future studies need to focus on identifying whitefly natural enemies and designing environment-friendly whitefly control methods such as use of virus resistant tomato varieties, use of mulches, and uprooting infected tomato plants.

Another control measure for whitefly and TYLCV generated from this study is a shift in planting date by utilising periods when whitefly populations are low. During our study, it was established that whitefly populations were low in May to June and October to November 1999. This may be variable over the years, and therefore continuous studies would be required to generate data for purposes of modelling whitefly population dynamics. As for now, initiation of nursery beds during whitefly-free periods would help to avoid primary TYLCV infection. The objective is to have mature plants with hardened leaves, which are not palatable to whiteflies by the time whitefly population rises again. Related non-pesticide methods for the control of whiteflies, such as use of plastic mulches, were found to be effective in the Middle East (Ioannu et al., 1991). Whereas our study considered several factors involved in influencing whitefly transmission of TYLCV, it is suggested that a system-wide /holistic approach to studying tomato yellow leaf curl viruses be applied in future studies on this subject. In conclusion, as observed during our study, rainfall patterns, uprooting, intercropping, and use of dimethoate insecticide influence whitefly populations, and hence influence TYLCV disease incidence.

At the same time, we cannot overlook the fact that tomatoes are grown by smallholder farmers, and in varying and complex agro-ecosystems, which are characterized by a rich Bio-diversity of crops. This situation enhances TYLCV transmission. Our study identified weed species associated with the tomato agro-ecosystem to be Ageratum conyzoides, Commelina benghalensis, Conyza floribunda, Crassocephalum spp., Desmodiumspp., Euphorbia heterophylla, Physalis floridana and Imperata cylindrica. At least three weeds, i.e. Euphorbia heterophylla, Physalis floridana and Desmodium spp. (Table 3.13), were confirmed to be TYLCV-UG alternative hosts. The existence of a monocyclic pattern of TYLCV disease could imply that it was transmitted from weeds to tomato in the experimental field, and no subsequent spread took place from tomato to tomato within the experiment. TYLCV transmission from weeds to tomato was also reported in Tanzania (NonoWomdim et al., 1996) and in the Middle East (Ioannou et al., 1991). On the other hand, Caciagli et al. (1995) reported a polycyclic pattern of TYLCV transmission from tomato to tomato by $B$. tabaci. Furthermore, beans, sweet potato and cassava found in the farming system, and as reported by Legg (1996), are alternative hosts of whiteflies. Consequently, we can conclude that timely weeding is also important in management of tomato yellow leaf curl diseases (sensu lato), in 
addition to running a proper crop rotation. Alternative crop hosts could play a big role in offering breeding grounds to tomato infesting whiteflies. It is important that future research establishes whether whiteflies observed on other crop hosts are vectors of tomato yellow leaf curl diseases. Even though this information is not available in Uganda, use of these whitefly and tomato yellow leaf curl viruses alternative host crops as tomato intercrops should be discouraged, and instead crop rotation is recommended something, which may be difficult in a situation where smallholder farmers have scarce land and grow crops like cassava and sweet potato for food security. From another school of thought, whiteflies immigrations may also influence the effectiveness of whitefly management treatments, as was also observed by Cohen and Antignus (1994) in Jordan Valley and Simone and Short (1998) in Florida. According to our study, general whitefly population evolutions in the tomato field environment had the same trends, whether monitored with either sticky traps or Kubwa trap (Figures 5.1-5.2), even though they differed in magnitude. While yellow and blue sticky traps targeted whiteflies in the overall experiment environment, the Kubwa trap targeted whiteflies resting on tomato plants. Thus, absolute field populations of $\mathrm{B}$. tabaci are not easy to determine (Gerling and Mayer, 1995), any sticky traps would measure migrating whiteflies as well as those in trivial flights, (Cohen et al., 1988), defined as those movements, which cover very short distances within and between plants.

This is the case with yellow and blue sticky traps, which are fully exposed to the atmosphere. However, these traps are cheap, made of used plastic containers, and therefore affordable by farmers. Therefore, tomato farmers in Uganda can use these sticky traps as monitoring tools for whiteflies before making a decision to apply pesticides.

Changes in weather conditions influence tomato growing seasons and whitefly populations, which in turn influences incidence of tomato yellow leaf curl disease. Similarly, farmers' activities like planting date, weeding, and pesticide applications affect whitefly populations and tomato yellow leaf curl diseases incidence, as well as tomato fruit yield. Because of the variable treatments used in our experimental trials, control plots, and continuous planting, irrespective of weather conditions, our trials on average recorded lower yields than the reported average yield for Uganda (10 ton/ha), whereby farmers go for only optimum production periods of the year. Farmers apply excessive pesticides irrespective of pest population levels, in which case other pests that affected yields in our trials, like Helicoverpa armigera (African bollworm), are completely wiped out in farmers' trials. Therefore, we can deduce that the study proved null hypotheses to be true, and to have achieved set objectives. This way useful information, which can be used to generate appropriate whitefly and TYLCV management packages, is made available and future research gaps established.

\section{Recommendations}

Field studies of the virus-vector relationship established that virus occurrence varied in space and time, and with management practices, crop development stage, and weather conditions. A negative relationship $(\mathrm{R}=-0.14, \mathrm{p}=0.04)$ was established between number of plants infected with TYLCV (sensu lato) and percentage marketable tomato yield. On the other hand, Bemisia tabaci, the vector of TYLCV (sensu lato) showed a variable population, which depended on micro-climatic conditions in the agro-ecosystem, with high populations prevailing during the dry season and decreasing with the onset of rain, and in turn influenced tomato yellow leaf curl virus disease incidence. The more mature the tomato crop, the less it was infested with whiteflies $(\mathrm{R}=-0.5, \mathrm{p}<$ 0.0001), for whiteflies prefer tender leaves, which are found on young tomato plants (NonoWomdim et al., 1996). Therefore, variation in date of planting could be used in management of both whiteflies and TYLCV (sensu lato).

Furthermore, an integrated package of uprooting TYLCV disease symptom bearing plants and application of the insecticide dimethoate was found to be the most effective of the six treatments applied in reducing whitefly populations and controlling TYLCV (sensu lato). Perring et al. (1999), while considering the effect of epidemiological factors and transmission of insect-vectored viruses 
on the effectiveness of chemical treatments, found that the best approach to vector and virus disease management was to use more than one control measure.

Treatments applied during our study indicated that uprooting combined with application of dimethoate was the most effective control. Chan and Jeger (1994) reported that uprooting was more effective especially when plants are sparsely planted. Tomato is densely planted and canopies overlap. Even though, our finding indicated that at low disease incidence both chemical and uprooting were individually effective.

Vaseline-smeared sticky traps made from locally available 5 litre yellow plastic jerry cans, were used to monitor infestation. They trapped an average of 100 whiteflies per $1 \mathrm{~m}^{2}$, and had efficiency either of 483, 100 or 117 whiteflies per $1 \mathrm{~m}^{2}$ for the first, second, and third planting experiment, respectively.

\section{References}

Allen, R. N., R. T. Plumb, and J. M. Thresh, 1983. Spread of banana bunchy top and other plant virus diseases in time and space. In: Plant Virus Epidemiology. In: The Spread and Control of Insect-Borne Viruses. R. T. Plumb and J. M. Thresh (eds.), pp. 51-59.

Butler, G. D., Jr., and Henneberry, T. J. 1989. Sweet potato whitefly migration, population increase, and control on lettuce with cotton seed oil sprays. South-western Entomologist, 14:287-293.

Chiang, B. T., Nakhla, M. K., Maxwell, D. P., Schoenfelder, M., and Green S. K. 1996. A new Geminivirus Associated with leaf curl disease of Tomato in Tanzania. Plant Dis., 81: 111.

Czosnek, H., and Laterrot, H. 1997. A worldwide survey of tomato yellow leaf curl viruses. Arch. Virol. (1997) 142: 1391 - 1406.

Green, S. K. 1991. Guidelines for diagnostic work in plant Virology. AVRDC Tech. Bull. No. 15. $63 \mathrm{pp}$.

Legg, J. P. 1996. Host-associated strains within Ugandan populations of the whitefly Bemisia tabaci (Genn.), (Homoptera, Aleyrodidae). J. Appl. Entom., 120: 523 - 527.

Lewis, T. 1973. Thrips, their biology, ecology and economic importance, $323 \mathrm{pp}$.

Mazyad, H. M., Omar, F., Al-Taher, K., and Salha, M. 1979. Observations on the epidemiology of tomato yellow leaf curl disease on tomato plants. Plant Dis. Reptr., 63: 297- 975.

Mead, R., and Curnow, R. N. 1990 Statistical methods in Agriculture and Experimental Biology 3rd Edition Chapman and Hall, London, 333 pp.

Moustafa, S. E. 1991. Tomato cultivation and breeding program for Tomato yellow leaf curl virus. In Resistance of the Tomato to TYLCV, Proceedings of the seminar of EEC contract DG XII TS2 - A - 055 F (CD) partners. H. Laterrot, and C. Trousse, ed., INRA. pp. 6 - 8.

Mwaule, Y. W. 1995. Draft Report of the Consultancy on Tomato Research results in Uganda from 1980-1995, GTZ -IPM Horticulture Reports. 85 pp.

Nono-Womdim, R., Swai, I. S., Green, S. K., Gebre-Selassie, K., Laterrot, H., Marchoux, G., and Opena, R. T. 1996. Tomato viruses in Tanzania: identification, distribution and disease incidence. J. S. Afri. Soc. Hort. Sci. pp. 41 - 44.

Padidam, M., Beachy, R. N., and Fauquet, C. M. 1995. Classification and identification of Geminiviruses using sequence comparisons. General Virol., 76: 249 - 263.

Plumb, R. T, Thresh, J. M. 1983. Plant virus epidemiology. Blackwell Scientific Publications.

Polston, J. E., and Anderson, P. K., 1997. The emergence of Whitefly-transmitted Geminiviruses in Tomato in the Western Hemisphere. Plant Dis., 81(12): 1359 - 1369.

Raccah, B. 1986. Non-Persistent viruses: Epidemiology and control. Advances in Virus Research. Vol.31: 387 - 429.

Rice, R. P., Rice, L. W., and Tindall, H. D., 1987. Fruit and Vegetable Production in Africa. Macmillan Publishers, U.K. 371 pp.

Ssekyewa C. 2006 Incidence, Distribution and Characterization of Tomato Leaf Curl viruses and their Vectors in Uganda. A PhD Thesis. 133pgs, Ghent University, Ghent Belgium. 
Ssekyewa et al.

Ssekyewa C., Van Damme P., Steele K. A. 2009 Molecular Characterization of Leaf Curl DiseaseCausing Viruses in Uganda. J. of Science and Sustainable Development, 2:11-22.

\section{Author Biography}

Charles Ssekyewa is professor of Agriculture at Uganda Martyrs University. He is also the Director of the University's Research Directorate and a member of the International Society of Organic Agriculture Research (ISOFAR) Board.

Van Damme Patrick is professor of Agriculture and the Head of the Crop Production Department, Tropical, Sub-tropical Agriculture and Ethnobotany Laboratory, Faculty of Bioscience Engineering, Ghent University, Belgium.

Nagawa Florence is an Entomologist and a Team Leader at Fair Trade, Uganda.

Kyamanywa Samuel is professor of Agriculture and Dean, Faculty of Agriculture, Makerere University, Kampala.

Steele Katherine Andrea is a molecular breeder and Head, Molecular Breeding Laboratory, CAZS, Bangor University, Gwynedd, United Kingdom. 